\title{
PREFERENSI KONSUMEN TERHADAP PRODUK SASIRANGAN DI KOTA BANJARMASIN
}

\section{CUSTOMER PREFERENCES TOWARDS SASIRANGAN PRODUCTS IN CITY OF BANJARMASIN}

\author{
Herry Pradana ${ }^{1}$, Siska Fitriyanti ${ }^{2}$ \\ ${ }^{1,2}$ Badan Penelitian dan Pengembangan Daerah Provinsi Kalimantan Selatan \\ Jl. Dharma Praja 1 Komplek Perkantoran Pemerintah Provinsi Kalimantan Selatan, Banjarbaru, \\ Kalimantan Selatan, Indonesia \\ e-mail: herry.a.pradana@gmail.com
}

Diserahkan: 22/03/2021, Diperbaiki: 11/05/2021; Disetujui: 20/05/2021

DOI: $10.47441 / \mathrm{jkp} . v 16 \mathrm{i} 1.160$

\begin{abstract}
Abstrak
Sasirangan merupakan kain khas Kalimantan Selatan yang pada wal kehadirannya merupakan pakaian bagi Raja dan kaum bangsawan di Kalimantan Selatan. Saat ini, sasirangan telah banyak dipakai oleh semua kalangan masyarakat. Kota Banjarmasin telah menetapkan Sasirangan Pewarna Alam sebagai produk unggulan pada sektor ekonomi kreatif, berdasarkan rekomendasi dari Badan Ekonomi Kreatif di tahun 2017. Meski demikian, industri sasirangan belum banyak berkontribusi terhadap peningkatan taraf ekonomi para pelaku usahanya. Beberapa factor penyebabnya antara lain segmentasi pasar masih dalam daerah, belum banyak inovasi desain, serta masih kalah bersaingan dengan produk sejenis lainnya di tingkat regional dan nasional. Penelitian ini bertujuan untuk mengetahui preferensi konsumen produk sasirangan guna mendapatkan strategi pengembangan produk sasirangan. Penelitian ini menggunakan metode deskriptifeksploratif. Sebanyak 275 responden dipilih secara acak melalui penyebaran kuesioner online. Data primer lainnya juga didapatkan dari wawancara dan FGD. Hasil penelitian menunjukkan preferensi utama konsumen dalam membeli produk sasirangan adalah kombinasi warna, motif, kenyamanan, harga, jenis pewarna (alam atau sintetis), trend, dan merek. Secara umum, hasil penelitian ini menegaskan bahwa pasar yang pas untuk sasirangan adalah menempatkan produk sasirangan pewarna alam sebagai produk premium. Agar niche market ini dapat berhasil, maka pemasaran sasirangan harus intensif melalui semua channel yang tersedia.
\end{abstract}

Kata Kunci: Sasirangan, Preferensi Konsumen, Pemasaran

\section{Abstract}

Sasirangan is a craft cloth from South Kalimantan, which was originally the clothing of the nobility in South Kalimantan. Currently, it has been widely used by all circles of society. The City of Banjarmasin has determined Sasirangan Natural Dyes as a superior product in the creative economy sector in 2017. However, the industry has not contributed much to improve the economic of its business actors because of market segmentation that is still in the region, lack of design innovations, and still unable to compete with other similar products at national level. This study aims to determine consumer preferences to obtain a strategy for developing sasirangan products. This research uses descriptiveexploratory method. Primary data was taken by online questionnaires of 275 respondents were selected randomly, interviews and FGD. The results showed that the main preferences of consumers were a combination of colors, motifs, comfort, price, types of dyes (natural or synthetic), trends, and brands. The results of this study confirm that the right market for sasirangan is to place natural dye sasirangan products as premium products. For this niche market to be successful, sasirangan marketing must be intensive through all available channels.

Keywords: Sasirangan, Customer Preferences, Marketing 


\section{PENDAHULUAN}

Praktik telah membuktikan bahwa pembangunan struktural yang sistematis pada sektor ekonomi kreatif berdampak besar terhadap perkembangan ekonomi negara maju bahkan berkembang. Pengembangan sektor ekonomi kreatif, khususnya yang terkait dengan kearifan lokal kerap dianggap sebagai salah satu tema utama pembangunan potensi ekonomi kreatif sebuah negara (Żelazny 2017). Pergeseran paradigma yang menggunakan komoditas sumber daya alam sebagai penggerak utama dan tulang punggung perekonomian menuju perekonomian berbasis iptek dan kreativitas tampaknya menjadi katalisator perubahan struktur perekonomian negara-negara di dunia (Higgs and Cunningham 2008) (Howkins 2001). Untuk mempersiapkan perubahan paradigma ini, masyarakat harus memahami bagaimana cara terbaik untuk mengembangkan industri kreatif, terutama dalam hal bertumpu pada kreativitas dan konsep inovasi (Hidayat 2017) (Darwanto 2013).

Tren permintaan dan produksi pada industry fashion mengalami kenaikan khususnya pada dekade terakhir ini, dimana terjadi pertumbuhan permintaan sebesar $13 \%$ setiap tahunnya (Barnes 2006). Pertumbuhan ini juga pada akhirnya berdampak pada berubahnya dinamika dalam industri fashion, dimana mulai ditinggalkannya produksi massal yang dinilai tidak etis dan banyak melanggar aturan ketenagakerjaan, perubahan rantai pasok, permintaan untuk biaya yang lebih rendah, dan fleksibilitas dalam desain, logistik, dan distribusi (Doyle 2006). Sebelumnya, pelanggan lebih memperhatikan harga dan ketersediaan produk, tetapi sekarang preferensi pelanggan berbeda dalam kaitannya dengan produk dan layanan (Powers 2012). Fokus pemasaran telah bergeser dari perusahaan ke pelanggan, dan sekarang kembali bergeser kepada pola pemasaran digital dengan fokus pada customer-centric, user-generated, pola interaksi yang interaktif dan dinamis, serta mendorong adanya partisipasi komunitas (Smith 2017). Pelanggan saat ini mewakili audiens yang proaktif, mereka lebih mengontrol eksposisi mereka terhadap upaya pemasaran (Stelzner 2017), dimana para palanggan memiliki peranan dalam memilih, serta membuat konten pemasaran (Iosub 2016).

Secara khusus, meskipun tren di industri pada umumnya mulai bergeser kepada pemasaran digital atau toko online, tetapi sebagian besar konsumen masih memilih berbelanja langsung ke pasar atau toko yang keberadaan fisiknya jelas (Shanthi 2015). Preferensi seseorang dalam membeli suatu produk, baik secara online maupun tradisional dipengaruhi oleh faktor kepribadian yang dimiliki oleh orang tersebut. Oleh karena itu, preferensi belanja konsumen diartikan sebagai selera konsumen yang diukur dengan persepsi kegunaan dan manfaat produk yang ditawarkan (Gulera 2015). Preferensi belanja berkaitan dengan metode belanja yang disukai atau tidak disukai seseorang dan tidak dipengaruhi oleh daya beli konsumen, hal inilah biasanya memengaruhi keputusan pembelian (Katawetawaraks 2013). Sehingga fokus pelaku usaha dalam memahami konsumen dan mengerti prefrensi mereka merupakan kunci untuk menjaga konsumen dan loyal kepada penjual (Lubis 2016).

Sejalan dengan perlambatan ekonomi di Kalimantan Selatan khususnya pada sektor pertambangan dan pertanian, pengembangan sektor ekonomi kreatif dapat menjadi salah satu solusi praktis yang berkelanjutan bagi perekonomian Kalimantan Selatan (Pradana and Fitriyanti 2019). Namun sejauh ini Pemerintah Provinsi Kalimantan Selatan belum memiliki regulasi khusus mengenai sektor ekonomi kreatif, baik dalam bentuk peraturan daerah maupun peraturan gubernur. Meskipun demikian, industri perbankan memberikan peluang yang sangat besar kepada pelaku ekonomi kreatif untuk pengembangan usahanya, khususnya dalam penyediaan pinjaman lunak. Di sisi lain, sekalipun pembinaan pelaku ekonomi kreatif berbasis ekonomi lokal dapat memperluas jaringan dan inovasi sehingga produk yang dihasilkan memiliki nilai jual yang tinggi, namun pembinaan bagi peserta ekonomi kreatif masih tidak merata di masing-masing wilayah (Hoxha 2019). 
Kota Banjarmasin telah menetapkan Sasirangan Pewarna Alam sebagai produk unggulan pada sektor ekonomi kreatif, setelah melalui rekomendasi dari Badan Ekonomi Kreatif di tahun 2017. Permasalahan utamanya adalah, Sasirangan masih belum begitu popular di kalangan generasi milenial dan anak muda, serta desain masih belum banyak menunjukan perubahan dalam satu dekade terakhir (H. A. Pradana 2020). Sasirangan masih kalah bersaingan dengan produk Batik, Tenun, Songket, dan produk sejenis lainnya di tingkat regional dan nasional, sehingga belum banyak berkontribusi terhadap peningkatan taraf ekonomi para pengrajin dan desainer Sasirangan. Oleh karena itu, faktor preferensi konsumen menjadi sangat vital untuk diteliti lebih dalam guna mendapatkan strategi pengembangan produk Sasirangan agar dapat bersaing dengan produk sejenis lainnya, serta juga dapat menjaring segmen anak muda dalam penjualan produk-produk berbahan sasirangan.

\section{METODE PENELITIAN}

Penelitian dilaksanakan menggunakan metode deskriptif-eksploratif untuk menggali lebih dalam mengenai prefrensi konsumen dalam memilih produk sasirangan yang ada dipasar. Dengan model ini, tim peneliti dapat melakukan identifikasi secara mendalam potensi pasar dari produk sasirangan serta apa saja hambatan-hambatan pengembangannya. Melalui alat analisis ini juga akan didapat model pemasaran produk sasirangan yang tepat dalam rangka sebagai salah satu produk unggulan subsektor kriya di Kota Banjarmasin, Ada sebanyak 275 responden dalam penelitian ini yang mengisi formular survei online, berlangsung dari 28 Maret hingga 28 April 2019. Pemilihan responden berdasarkan kombinasi teknik nonprobability sampling (purposive dan convinience). Selain itu data primer diambil Diskusi Kelompok Terarah (FGD) dan wawancara mendalam. Data sekunder didapatkan melalui studi kepustakaan.

\section{HASIL DAN PEMBAHASAN}

Responden diberikan kuesioner online yang terdiri atas beberapa pertanyaan mengenai berbagai aspek yang mempengaruhi keputusan responden dalam membeli sasirangan. Aspek-aspek tersebut meliputi kenyamanan, harga, merek, warna, tren motif, dan jenis pewarna (pewarna alami atau kimia/sintetis). engan menggunakan nonprobability sampling. Meskipun termasuk nonprobality sampling, namun diharapkan ada stratifikasi agar tetap ada keterwakilan antar stratifikasi. Dengan demikian responden dapat mewakili berbagai karakteristik yang berbeda secara demografi seperti jenis kelamin dan kelompok umur; karakteristik ekonomi (pekerjaan dan pendapatan); karakteristik sosial (pendidikan); serta karakteristik geografis, yakni domilisi atau tempat tinggal. Pertanyaan-pertanyaan dalam kuesioner survei ini dibuat menggunakan google survey. Link kuesioner survei didistribusikan melalui grup Whatsapp dan media sosial lainnya oleh masing-masing peneliti dengan berbagai latar belakang yang berbeda. Kuesioner ini secara khusus juga disebarkan di lingkungan Pemerintah Kota Banjarmasin melalui Barenlitbangda Kota Banjarmasin.

Selama satu bulan kuesioner survei sejak pertama diluncurkan, ada sebanyak 275 responden yang secara sukarela berpartisipasi telah mengisi kuesioner online secara mandiri. Dari sejumlah tersebut jika dilihat menurut jenis kelamin, partisipan survei lebih didominasi oleh perempuan sebanyak 168 orang atau setara dengan 59,79\%. Sisanya 40,21\% adalah laki-laki. Dapat dilihat jika perempuan lebih bersedia meluangkan waktunya untuk mengisi kuesioner dibandingkan laki-laki. Berdasarkan domisilinya, lebih dari $90 \%$ responden tinggal di wilayah Provinsi Kalimantan Selatan. Lebih spesifik, mereka yang tinggal di Kota Banjarmasin ada sebanyak 45,20\%. Sedangkan di luar Banjarmasin namun masih dalam wilayah Kalimantan Selatan sebesar 46,26\%. Sisanya 8,54\% berdomisili di luar Kalimantan Selatan, seperti Jakarta, Jawa Barat, Banten, Jawa Tengah, Jawa Timur, Kalimantan Timur, Kalimantan Tengah, NTT, Bangka Belitung dan Sumatera Selatan. 
Responden dikelompokkan menjadi 3 (tiga) kelompok berdasarkan usia, yakni 25 tahun ke bawah; 26-40 tahun; dan 41 tahun ke atas. Ketiganya mencirikan kekhasan masing-masing. Usia 25 tahun ke bawah mempunyai karakter muda yang dinamis, usia 2640 tahun mencirikan kematangan dalam bertindak, dan 41 tahun ke atas adalah generasi tua yang berciri kedewasaan dalam berpikir. Berdasarkan kelompok umur tersebut, responden terbanyak berada pada kelompok umur 26-40 tahun sebanyak 54,09 persen. Kemudian disusul 41 tahun ke atas sebesar 35,59 persen. Sementara kelompok responden paling sedikit adalah usia muda yang meliputi 10,32 persen dari total responden.

Jika dilihat menurut pekerjaannya, responden yang berpartisipasi dalam survei ini terbanyak bekerja di sektor pemerintahan, yakni mencapai 2/3 dari total responden. Hal ini dapat dimaklumi karena link kuesioner lebih banyak disebarkan kepada para ASN, terutama di lingkungan pemerintah kota Banjarmasin sebagai pihak penyelenggara penelitian ini dan kolega dari tim peneliti yang juga PNS. Terbanyak kedua adalah mereka yang bekerja sebagai pengusaha/pegawai swasta yang meliputi lebih dari 1/5 dari seluruh responden. Adapun mereka yang berstatus "Lainnya" adalah di luar ASN dan pengusaha/pegawai swasta serta termasuk pula mereka yang tidak bekerja, baik sebagai ibu rumah tangga, sedang kuliah dan atau sekolah. Jumlah kelompok ini berkisar 12,18\%.

Karakteristik responden selanjutnya yang dilihat adalah tingkat pendidikan. Hampir setengah dari total responden berpendidikan S1 atau Diploma IV. Jumlah ini merupakan yang terbesar di antara pendidikan yang lain. Sedangkan yang berpendidikan S2/S3 mencapai 35,94 persen. Sisanya adalah Diploma III ke bawah. Ini cukup menggambarkan bahwa tingkat pendidikan responden cukup tinggi. Bahkan tidak ada dari responden yang berpendidikan SD ke bawah. Kondisi ini dimungkinkan terkait dengan pekerjaaan responden yang memang sebagian besarnya adalah PNS yang berpendidikan sarjana.

Hasil skoring menunjukkan bahwa aspek-aspek yang perlu diperhatikan saat membeli sasirangan dari yang paling tinggi hingga yang paling rendah adalah kenyamanan, harga, warna, tren motif, berbahan pewarna alam, dan merek. Konsumen sangat memperhatikan warna dan motif dalam memilih sasirangan. Jika sesuai dengan selera, konsumen akan memutuskan membeli. Sehingga kedua aspek ini memiliki nilai skor paling tinggi dalam preferensi memilih dan membeli produk sasirangan. Sedangkan variabel yang paling tidak diperhatikan dalam memilih dan membeli produk sasirangan adalah aspek merek. Skor aspek 'merek' bernilai 1 (satu) atau bahkan nyaris bernilai 0 (nol), yang berarti pengaruh merek hampir tidak ada dalam memilih sasirangan. Hal ini juga diperkuat di lapangan, hampir tidak ada sasirangan bermerek yang dominan di Kalimantan Selatan. Dengan demikian, merek belum bisa mencerminkan kualitas kain Sasirangan.

Jenis pewarna yang digunakan dalam hal ini penggunaan pewarna alam juga menjadi pertimbangan untuk membeli sasirangan, namun tidak sekuat pertimbangan pada aspek warna, motif, kenyamanan dan harga sebagai bahan pertimbangan utama. Beberapa konsumen bahkan tidak dapat membedakan antara sasirangan yang menggunakan pewarna alami dan yang menggunakan pewarna sintetis. Produk sasirangan yang terbuat dari pewarna alam memang tidak banyak tersedia di pasaran, hal ini menyebabkan konsumen tidak begitu memperhatikan terhadap sasirangan yang terbuat dari pewarna alam.

Preferensi konsumen dalam hal kenyamanan saat membeli produk sasirangan (dalam hal ini terkait dengan cara berbelanja produk sasirangan) juga menjadi aspek yang krusial sebagai pertimbangan dalam membeli produk sasirangan. Hal ini dikarenakan lokasi pembelian memiliki hubungan yang sangat erat dengan jalur distribusi pemasaran oleh produsen. Sebanyak 64 persen responden menjawab bahwa mereka membeli sasirangan di toko tempat sasirangan dijual, khususnya toko yang berlokasi di Kota Banjarmasin, Banjarbaru dan Martapura. Ketiga wilayah ini memang merupakan pusat pemasaran produk sasirangan di Kalimantan Selatan. 26 persen responden membeli langsung ke pengrajin Sasirangan, dan sisanya sekitar 9,09 persen mengaku membeli sasirangan melalui internet (melalui toko online atau platform e-commerce tertentu). 
Tabel 1. Persentase Responden Menurut Karakteristik Responden dan Metode Pembelian Produk Sasirangan

\begin{tabular}{|c|c|c|c|c|c|}
\hline \multirow{2}{*}{\multicolumn{2}{|c|}{ Karakteristik Responden }} & \multicolumn{4}{|c|}{ Metode Pembelian Sasirangan } \\
\hline & & \multirow{2}{*}{$\begin{array}{l}\text { Toko } \\
(2)\end{array}$} & \multirow{2}{*}{$\begin{array}{l}\text { Pengrajin } \\
(3)\end{array}$} & \multirow{2}{*}{$\begin{array}{l}\text { Online } \\
(4)\end{array}$} & \multirow{2}{*}{$\frac{\text { Total }}{(5)}$} \\
\hline & (1) & & & & \\
\hline \multirow[t]{3}{*}{ Jenis Kelamin } & Laki-laki & 66,36 & 27,27 & 6,36 & 100,00 \\
\hline & Perempuan & 63,03 & 26,06 & 10,91 & 100,00 \\
\hline & 25 tahun ke bawah & 50,00 & 28,57 & 21,42 & 100,00 \\
\hline \multirow[t]{2}{*}{ Usia } & 26 - 40 tahun & 64,63 & 25,17 & 10,20 & 100,00 \\
\hline & 41 tahun ke atas & 68,00 & 28,00 & 4,00 & 100,00 \\
\hline \multirow{3}{*}{ Pekerjaan } & PNS & 65,41 & 26,49 & 8,11 & 100,00 \\
\hline & $\begin{array}{l}\text { Pengusaha/Pegawai } \\
\text { Swasta }\end{array}$ & 63,64 & 25,45 & 10,91 & 100,00 \\
\hline & Lainnya & 60,00 & 28,57 & 11,43 & 100,00 \\
\hline \multirow{3}{*}{$\begin{array}{l}\text { Tingkat } \\
\text { Pendidikan }\end{array}$} & D III ke bawah & 66,67 & 26,19 & 7,14 & 100,00 \\
\hline & $\mathrm{S} 1$ & 63,24 & 24,26 & 12,50 & 100,00 \\
\hline & $\mathrm{S} 2 / \mathrm{S} 3$ & 64,95 & 29,90 & 5,15 & 100,00 \\
\hline \multirow{3}{*}{$\begin{array}{l}\text { Pendapatan } \\
\text { perbulan }\end{array}$} & di bawah 4 juta & 68,42 & 23,68 & 7,90 & 100,00 \\
\hline & $4-7$ juta & 57,02 & 33,33 & 9,64 & 100,00 \\
\hline & di atas 7 juta & 70,59 & 20,00 & 9,42 & 100,00 \\
\hline \multirow{4}{*}{$\begin{array}{l}\text { Tempat } \\
\text { Domisili }\end{array}$} & Banjarmasin & 58,40 & 35,20 & 6,40 & 100,00 \\
\hline & Kalsel(Selain & 7154 & & & \\
\hline & Banjarmasin) & 71,54 & 18,46 & 10,00 & 100,00 \\
\hline & Luar Kalsel & 55,00 & 25,00 & 20,00 & 100,00 \\
\hline
\end{tabular}

Sumber: data primer yang diolah 2019

Berdasarkan tabel 1, masih sedikit responden yang memanfaatkan metode belanja online. Hal ini dapat disebabkan masih sedikitnya penjual sasirangan yang memasarkan produk sasirangan secara online. Responden yang paling banyak membeli via online adalah yang berusia 25 tahun ke bawah dan yang tinggal di luar Kalimantan Selatan. Pada era digital seperti sekarang ini, potensi penjualan melalui online sangatlah besar, karena jangkauan pasarnya lebih luas dan dapat meningkatkan exposure produk di pasar global. Menjual produk secara online juga banyak memberikan kemudahan dan keuntungan bagi pedagang maupun pengrajin. Pangsa pasar jelas semakin luas, bahkan dapat menembus market luar negeri.

Penggunaan kain sasirangan sebagian besar masih digunakan untuk kegiatan formal. Sasirangan saat ini memang paling banyak dipakai oleh pegawai pemerintahan, swasta dan pelajar. Keharusan menggunakan sasirangan di lingkup pemerintahan dan sekolah adalah salah satu bentuk implementasi Peraturan Daerah (Perda) Kota Banjarmasin Nomor 19 Tahun 2014 tentang Pelestarian Seni dan Budaya Daerah. Meski demikian, berjualan secara online juga menyisakan kekhawatiran bagi banyak pelaku usaha sasirangan. Berdasarkan hasil wawancara dengan pengrajin dan penjual sasirangan, mereka menilai konsumen di Kalimantan Selatan masih lebih memilih membeli langsung ke toko dibandingkan membeli secara online. Selain itu, ada kekhawatiran desain yang mereka buat akan ditiru oleh orang lain, sehingga lebih memilih untuk tidak memajang desain, motif dan kombinasi warna sasirangan yang mereka miliki pada media online.

\section{Preferensi Konsumen terhadap Sasirangan}

Preferensi konsumen terhadap produk sasirangan merupakan fokus utama dari penelitian ini. Hasil preferensi konsumen dapat menjadi bahan evaluasi dan perencanaan bagi pemerintah dan pelaku industri sasirangan dan dapat menjadi pertimbangan dalam mengembangkan produk sasirangan kedepannya. 
Tabel 2. Persentase Responden Menurut Karakteristik Responden dan Jenis Kain Daerah yang Disukai

\begin{tabular}{|c|c|c|c|c|c|}
\hline \multirow{2}{*}{\multicolumn{2}{|c|}{ Karakteristik Responden }} & \multicolumn{4}{|c|}{ Jenis Kain Daerah yg Disukai } \\
\hline & & \multirow{2}{*}{$\begin{array}{c}\text { Batik } \\
(2)\end{array}$} & \multirow{2}{*}{$\begin{array}{c}\text { Sasirangan } \\
\text { (3) }\end{array}$} & \multirow{2}{*}{$\begin{array}{c}\text { Lainnya } \\
\text { (4) }\end{array}$} & \multirow{2}{*}{$\begin{array}{c}\text { Total } \\
(5)\end{array}$} \\
\hline & (1) & & & & \\
\hline \multirow[t]{2}{*}{ Jenis Kelamin } & Laki-laki & 38,18 & 52,73 & 9,09 & 100,00 \\
\hline & Perempuan & 35,15 & 54,55 & 10,30 & 100,00 \\
\hline \multirow[t]{3}{*}{ Usia } & $<25$ tahun & 60,71 & 39,29 & 0,00 & 100,00 \\
\hline & 26 - 40 tahun & 29,93 & 57,82 & 12,24 & 100,00 \\
\hline & $>41$ tahun & 39,00 & 52,00 & 9,00 & 100,00 \\
\hline \multirow[t]{3}{*}{ Pekerjaan } & PNS & 37,84 & 52,97 & 9,19 & 100,00 \\
\hline & Swasta & 40,00 & 49,09 & 10,91 & 100,00 \\
\hline & Lainnya & 22,86 & 65,71 & 11,43 & 100,00 \\
\hline Tingkat & $<$ D III & 38,10 & 57,14 & 4,76 & 100,00 \\
\hline \multirow[t]{2}{*}{ Pendidikan } & $\mathrm{S} 1$ & 33,09 & 56,62 & 10,29 & 100,00 \\
\hline & $\mathrm{S} 2 / \mathrm{S} 3$ & 40,21 & 48,45 & 11,34 & 100,00 \\
\hline Pendapatan & $<4$ juta & 27,63 & 63,16 & 9,21 & 100,00 \\
\hline \multirow[t]{2}{*}{ perbulan } & $4-7$ juta & 37,72 & 48,25 & 14,04 & 100,00 \\
\hline & $>7$ juta & 42,35 & 52,94 & 4,71 & 100,00 \\
\hline Tempat & Banjarmasin & 36,00 & 52,00 & 12,00 & 100,00 \\
\hline \multirow[t]{3}{*}{ Domisili } & Kalsel (Selain Bjm) & 32,31 & 60,77 & 6,92 & 100,00 \\
\hline & Luar Kalsel & 65,00 & 20,00 & 15,00 & 100,00 \\
\hline & Total & 36,36 & 53,82 & 9,82 & 100,00 \\
\hline
\end{tabular}

Sumber: Data primer yang diolah 2019

Tabel 2 memberikan gambaran mengenai segementasi pasar sasirangan menurut berbagai karakteristik: demografi, ekonomi, sosial, dan geografis. Pada umumnya responden pada klasifikasi manapun dari setiap karakteristik jenis kelamin, pekerjaan, tingkat pendidikan, dan pendapatan di Kalimantan Selatan lebih banyak yang menyukai sasirangan dibandingkan batik dan kain khas daerah lainnya (pengecualian pada aspek usia dan domisili). Responden dengan usia 25 tahun ke bawah lebih banyak yang menyukai batik dibandingkan sasirangan. Dalam hal selera, terlihat anak muda yang masih pada usia sekolah dan kuliah lebih memilih batik dibandingkan sasirangan. Preferensi ini diduga dipengaruhi oleh beragamnya motif batik yang tersedia sesuai selera anak muda. Di sisi lain, responden dengan usia 26 tahun ke atas masih lebih dominan menyukai sasirangan.

Sementara pada karakteristik domisili, mereka yang tinggal di luar wilayah Kalimantan Selatan lebih menyukai batik dan kain daerah lainnya dengan persentase yang sangat besar yakni 80 persen. Hanya 20 persen saja yang menyukai sasirangan. Mereka yang tinggal di luar Kalimantan mungkin saja tidak terlalu mengetahui tentang sasirangan. Keterbatasan informasi tentang sasirangan dan masih kecilnya pangsa pasar sasirangan di luar Kalimantan Selatan menjadi tantangan bagi pelaku industri sasirangan beserta pihak pemangku kepentingan. Berdasarkan gambaran segmentasi pasar sasirangan menurut jenis produk sasirangan yang disukai dari setiap karakteristik responden, maka terdapat beberapa jenis produk sasirangan, yakni sasirangan dengan pewarna sintetis, sasirangan dengan pewarna alam, sasirangan dengan bordir, sasirangan berbahan kain dari sutera, dan sasirangan printing. Semua responden dari berbagai karakteristik menyatakan menyukai produk sasirangan dengan pewarna alam. Hasil ini menjadi selaras dengan komitmen Pemerintah Kota Banjarmasin untuk mengembangkan sasirangan pewarna alam sebagai salah satu produk unggulan Kota Banjarmasin. Selama ini, segmen sasirangan pewarna alam lebih dominan dari luar Kalimantan Selatan yang memang penyuka kain-kain yang mempunyai kearifan dan kekhasan lokal. Sedangkan untuk masyarakat Kalimantan 
Selatan, lebih cenderung memilih sasirangan dengan pewarna sintetis yang menghasilkan sasirangan dengan warna-warna cerah dan kuat.

Suplai sasirangan pewarna alam sudah ada dan mulai bertambah dari waktu ke waktu. Meskipun jumlah pengrajin sasirangan pewarna alam masih sangat sedikit jumlahnya, akan tetapi hasil survei mengindikasikan bahwa peluang pasarnya cukup besar. Kendala utamanya pengolahan sairangan pewana alam adalah dari sisi produksi, dimana bahan baku pewarna alam masih cukup sulit ditemui dipasar dan harus diolah terlebih dahulu. Proses ekstraksi warna juga memakan waktu cukup lama karena masih dilakukan secara manual, sehingga masih sulit untuk memenuhi permintaan secara massal atau dalam jumlah yang besar. Konsistensi warna juga kerap kali menjadi masalah dalam produksi sasirangan pewarna alam. Hal ini dikarenakan konsentrasi zat warna tidak dapat diperkirakan secara pasti dalam suatu hasil ekstraksi, sehingga seringkali terjadi inkonsistensi warna jika diproduksi secara banyak.

Jika ditelaah berdasarkan pada jenis dan desain sasirangan yang disukai oleh konsumen, ternyata konsumen tidak hanya menyukai jenis dan/atau desain tertentu saja. Hasil survei menunjukkan konsumen menyukai lebih dari satu jenis, atau dengan kata lain kombinasi pada beberapa desain dengan cakupan 41,45 persen. Desain yang paling tidak diminati adalah futuristik kontemporer yang hanya diminati oleh 5,45 persen responden saja. Yang berbeda hanya pada responden usia 25 tahun ke bawah saja yang lebih memilih desain sasirangan yang minimalis.

Berdasarkan preferensi konsumen terhadap warna sasirangan, responden pada umumnya lebih menyukai warna pastel. Sekitar 42,55 persen menyukai warna jenis ini. Sementara warna yang paling sedikit diminati adalah warna monokrom. Ada hal yang unik pada karakteristik jenis kelamin. Laki-laki lebih menyukai sasirangan yang colorful, sementara perempuan lebih menyukai warna pastel. Hal yang juga terjadi pada karakteristik domisili. Mereka yang tinggal di luar Kalimantan Selatan lebih menyukai warna colorful, sedangkan yang tinggal di Kalimantan Selatan lebih menyukai warna pastel.

Temuan yang dirangkum pada tabel 4 semakin mempertegas segmentasi pasar jenis sasirangan. Jika sebelumnya mereka hanya sekedar menyukai sasirangan pewarna alam, pertanyaan ini menujukkan kesediaan mereka membeli produk dengan pewarna alam. Hasilnya sangat dominan, menyatakan berminat membeli produk dengan pewarna alam. Hal ini menunjukkan potensi pasar besar bagi pengembangan produk sasirangan pewarna alam. Tinggal bagaimana meracik program yang mendukung agar produk sasirangan pewarna alam menjadi lebih berkembang.

\section{Penilaian dan Prospek Terhadap Produk Sasirangan}

Responden diberikan pertanyaan mengenai kekurangan dan kelebihan produk sasirangan. Desain monoton merupakan jawaban yang paling banyak dipilih oleh responden. Dilihat dari motif, produk sasirangan masih banyak berkutat pada motif klasik atau yang telah menjadi pakem sejak dahulu. Padahal prospek kedepannya, motik sasirangan yang lebih modern yang menyesuaikan dengan tren mode memiliki peluang pasar yang besar. Tabel 5 menunjukan aspek-aspek yang dianggap menjadi faktor-faktor kekurangan dan kelebihan dari produk sasirangan. 
Tabel 3. Persentase Responden Menurut Karakteristik Responden dan Jenis Warna Sasirangan yang Disuka

\begin{tabular}{|c|c|c|c|c|c|}
\hline \multirow{2}{*}{\multicolumn{2}{|c|}{ Karakteristik Responden }} & \multicolumn{4}{|c|}{ Jenis Warna Sasirangan yang Disuka } \\
\hline & & \multirow{2}{*}{$\begin{array}{c}\text { Colorful } \\
-2 \\
\end{array}$} & \multirow{2}{*}{$\begin{array}{c}\text { Monokrom } \\
-3\end{array}$} & \multirow{2}{*}{$\begin{array}{c}\text { Pastel } \\
-4\end{array}$} & \multirow{2}{*}{$\begin{array}{c}\begin{array}{c}\text { Lainnya / } \\
\text { Kombinasi }\end{array} \\
-5\end{array}$} \\
\hline & -1 & & & & \\
\hline Jenis & Laki-laki & 32.73 & 7.27 & 42.73 & $17: 27$ \\
\hline Kelamin & Perempuan & 26.67 & 4.24 & 42.42 & 26.67 \\
\hline \multirow{3}{*}{ Usia } & 25 tahun ke bawah & 7.14 & 10.71 & 67.86 & $14: 29$ \\
\hline & 26 - 40 tahun & 29.93 & 2.72 & 42.18 & 25.17 \\
\hline & 41 tahun ke atas & 34.00 & 8.00 & 36.00 & $22: 00$ \\
\hline \multirow{3}{*}{ Pekerjaan } & PNS & 29.73 & 3.78 & 40.54 & 25.95 \\
\hline & $\begin{array}{l}\text { Pengusaha/Pegawai } \\
\text { Swasta }\end{array}$ & 29.09 & 7.27 & 47.27 & $16: 36$ \\
\hline & Lainnya & 25.71 & $11: 43$ & 45.71 & $17: 14$ \\
\hline \multirow{3}{*}{$\begin{array}{l}\text { Tingkat } \\
\text { Pendidikan }\end{array}$} & D III ke bawah & 23.81 & 7.14 & 61.90 & 7.14 \\
\hline & $\mathrm{S} 1$ & 25.00 & 7.35 & 42.65 & 25.00 \\
\hline & $\mathrm{S} 2 / \mathrm{S} 3$ & 37.11 & 2.06 & 34.02 & 26.80 \\
\hline \multirow{3}{*}{$\begin{array}{l}\text { Pendapatan } \\
\text { perbulan }\end{array}$} & di bawah 4 juta & 34.21 & 5.26 & 43.42 & $17: 11$ \\
\hline & $4-7$ juta & 24.56 & 2.63 & 42.98 & 29.82 \\
\hline & di atas 7 juta & 30.59 & 9.41 & 41.18 & 18.82 \\
\hline \multirow{4}{*}{$\begin{array}{l}\text { Tempat } \\
\text { Domisili }\end{array}$} & Banjarmasin & 31.20 & 5.60 & 41.60 & 21.56 \\
\hline & $\begin{array}{l}\text { Kalsel (Selain } \\
\text { Banjarmasin) }\end{array}$ & 25.38 & 5.38 & 45.38 & 23.85 \\
\hline & Luar Kalsel & 40.00 & 5.00 & 30.00 & 25.00 \\
\hline & Total & 29.09 & 5.45 & 42.55 & 22.91 \\
\hline
\end{tabular}

Sumber: Data primer yang diolah 2019 
Tabel 4. Persentase Responden Menurut Karakteristik Responden dan Peminatan Membeli Produk dengan Pewarna Alam

\begin{tabular}{llccc}
\hline \multirow{2}{*}{ Karakteristik Responden } & \multicolumn{3}{c}{ Minat Beli Produk dengan Pewarna } \\
\cline { 2 - 4 } & & Yam & Tidak & Total \\
\cline { 2 - 4 } Jenis Kelamin & Laki-laki & 74,55 & 25,45 & 100,00 \\
& Perempuan & 78,18 & 21,82 & 100,00 \\
& Total & 76,73 & 23,27 & 100,00 \\
\hline Usia & 25 tahun ke bawah & 67,86 & 32,14 & 100,00 \\
& 26 - 40 tahun & 73,47 & 26,53 & 100,00 \\
& 41 tahun ke atas & 84,00 & 16,00 & 100,00 \\
\hline Pekerjaan & PNS & 78,38 & 21,62 & 100,00 \\
& Pengusaha/Pegawai Swasta & 83,64 & 16,36 & 100,00 \\
& Lainnya & 57,14 & 42,86 & 100,00 \\
\hline Tingkat & D III ke bawah & 71,43 & 28,57 & 100,00 \\
Pendidikan & S1 & 79,41 & 20,59 & 100,00 \\
& S2/S3 & 75,26 & 24,74 & 100,00 \\
\hline Pendapatan & di bawah 4 juta & 61,84 & 38,16 & 100,00 \\
perbulan & 4 - 7 juta & 78,95 & 21,05 & 100,00 \\
& di atas 7 juta & 87,06 & 12,94 & 100,00 \\
\hline Tempat & Banjarmasin & 78,40 & 21,60 & 100,00 \\
Domisili & Kalsel (Selain Banjarmasin) & 76,92 & 23,08 & 100,00 \\
& Luar Kalsel & 65,00 & 35,00 & 100,00 \\
\hline & Total & 76,73 & 23,27 & 100,00 \\
\hline
\end{tabular}

Sumber: Data Primer Peneliti 2019

Tabel 5. Jumlah dan Persentase Responden Berdasarkan Aspek yang Dinilai

\begin{tabular}{llcc}
\hline & Aspek yang Dinilai & Jumlah & Persentase \\
\hline & \multicolumn{1}{c}{$(\mathbf{1})$} & $\mathbf{( 2 )}$ & $\mathbf{( 3 )}$ \\
\hline Kekurangan & Desain monoton & 78 & 28,4 \\
produk & Desain tidak menarik & 21 & 7,6 \\
sasirangan & Desain ketinggalan jaman & 8 & 2,9 \\
& Harga mahal & 46 & 16,7 \\
& Lainnya / kombinasi & 122 & 44,4 \\
& Total & 275 & 100,0 \\
\hline Kelebihan & Desain beragam & 33 & 12,0 \\
produk & Desain menarik & 35 & 12,7 \\
sasirangan & Desain mengikuti model & 14 & 5,1 \\
& Harga terjangkau & 81 & 29,5 \\
& Lainnya / kombinasi & 112 & 40,7 \\
& Total & 275 & 100,0 \\
\hline
\end{tabular}

Sumber: Data Primer Peneliti 2019

Meski beberapa responden menilai desain sasirangan masih monoton, produk sasirangan mempunyai keunggulan dalam hal harga. Sebagian besar jenis sasirangan yang umum beredar di pasaran harganya relatif terjangkau, jika dibandingkan dengan produk khas daerah lainnya seperti kain songket, tenun pagatan dan beberapa kain daerah lain yang mempunyai harga lebih mahal. Dengan berbagai kekurangan dan kelebihan yang dimiliki sasirangan saat ini, Responden menyatakan prospek pengembangan sasirangan pewarna alam kedepannya sangat berpotensi. Hal ini dilatarbelakangi oleh berbagai alasan yang diutarakan oleh responden antara lain: (a) kesadaran penggunaan produk yang ramah lingkungan seperti pewarna alam kedepannya ditengarai akan semakin meningkat. Banyak orang yang semakin menggemari produk dengan kekhasan lokal yang ramah lingkungan. Dunia saat ini sedang mengampanyekan gerakan go green, termasuk penggunaan bahan 
baku industri yang ramah lingkungan; (b) sasirangan pewarna alam merupakan ciri khas asli sasirangan. Dengan kata lain, mengembangkan kembali sasirangan pewarna alam adalah mengembalikan identitas sasirangan sebenarnya; dan (c) adanya dukungan dari pemerintah daerah khususnya Pemerintah Kota Banjarmasin sudah jelas berada pada posisi mendukung pengembangan sasirangan pewarna alam.

Meski demikian, di balik prospek tersebut sebenarnya ada beberapa tantangan dalam rangka pengembangan produk sasirang berbahan pewarna alam sepertinya warna yang kurang terang, harga relatif lebih mahal dan desain motif yang belum menarik. Responden kemudian memberikan beberapa harapan agar pewarna alam tetap dapat diminati oleh konsumen. Ada 3 (tiga) harapan utama dari responden terkait pengembangan produk sasirangan pewarna alam, yaitu sosialisasi, promosi, serta membuka peluang pemasaran untuk konsumen mancanegara. Sosialisasi dan promosi harus gencar dilakukan baik oleh pemerintah, maupun pelaku usaha, agar masyarakat menjadi lebih mengenal produk sasirangan dengan pewarna alam. Mengadakan expo, pameran, dan festival secara rutin dapat memperkuat branding produk sasirngan sebagai produk khas daerah Kalimantan Selatan. Lomba desain motif juga harus sering diadakan agar sasirangan pewarna alam dapat terus dikembangkan sesuai dengan tren dan selera pasar.

\section{Segmentasi, Targeting dan Positioning Produk Sasirangan Pewarna Alam}

Pelaku usaha hendaknya terlebih dahulu harus melakukan segmentasi pasar, kemudian penargetan, serta pemposisian produk yang akan dijual untuk mencapai hasil pemasaran yang optimal (Kotler and Lane 2013). Segmentasi pasar pada intinya membagi potensi pasar menjadi bagian-bagian tertentu, berdasarkan pembagian demografis, geografis, ataupun juga berdasarkan gaya hidup (psikografis). Setelah proses segmentasi atas produk telah ditetapkan, maka langkah berikutnya adalah melakukan targeting atau membidik target market yang telah kita pilih dalam analisa segmentasi pasar. Dalam hal ini tentu saja serangkaian program pemasaran yang dilakukan harus sesuai dengan karakteristik pasar sasaran yang hendak kita tuju (Newbigin 2019).

Setelah targeting maka langkah selanjutnya adalah melakukan positioning produk, langkah ini artinya adalah menciptakan keunikan posisi produk dalam benak atau persepsi pelanggan potensial yang akan dibidik. Positioning yang tepat menjadi sangat penting agar dapat meraih perhatian pelanggan, yang selanjutnya hal ini dapat mendorong mereka untuk melakukan pembelian produk yang ditawarkan.

\section{Segmentasi Produk Sasirangan Pewarna Alam}

Secara keseluruhan, cerug pasar (niche market) diidentifikasikan oleh mayoritas responden sebagai segmen pasar (Nurcahyo 2018). Segmen yang dimaksud adalah sebagai strategi yang diterapkan pelaku usaha sasirangan untuk fokus ke pelanggan tertentu, yaitu konsumen yang gemar dengan produk khas daerah (Hussein 2019). Pengrajin sasirangan pewarna alam juga mengatakan bahwa sasirangan pewarna alam di Banjarmasin memiliki ciri khas tersendiri dengan mengkombinasikan desain dengan tren yang sedang berkembang menurut selera pasar tetapi tidak melupakan tentang dampak limbahnya terhadap lingkungan. Hal ini membawa daya tarik bagi wisatawan dalam negeri maupun luar negeri dengan adanya pameran seni expo berbasis kearifan lokal dan kerajinan yang sering diadakan pemerintah kota banjarmasin memungkinkan industri sasirangan pewarna alam terus berkembang di masa depan (Putra 2017).

Para pelaku usaha dari sektor fashion khususnya maupun produk kerajinan sasirangan pewarna alam lainnya sepakat bahwa dengan mengimplementasikan niche market, pelaku usaha mendapatkan efek positif yang berupa keuntungan dari produk yang mereka jual. Memiliki segmentasi pasar yang khusus menjadikan pelaku usaha sasirangan pewarna alam lebih fokus dalam melayani dan mengenali pelanggan mereka. Selera pasar dan tren yang berkembang lebih mudah terbaca oleh pengrajin karena pangsa pasarnya yang jelas. 
Lokasi penjualan yang tepat merupakan faktor yang berpengaruh penting bagi pengrajin sasirangan pewarna alam. Faktor ini berkaitan dengan konsep pemasaran produk sasirangan pewarna alam, dimana pengrajin hanya melayani atau menjual di wilayah atau lokasi tertentu. Hal ini ditunjukan bahwa seluruh pengrajin tersebut hanya menjual produknya (mayoritas) di wilayah Sentra Industri Sasirangan Kota Banjarmasin.

Sasirangan pewarna alam cenderung memiliki harga yang relatif lebih mahal dibandingkan sasirangan dengan pewarna sintetis. Hal ini menyebabkan segmen pasarnya pun menjadi lebih khusus, antara lain ASN (adanya kewajiban ASN di Kalimantan Selatan memakai pakaian Sasirangan setiap hari kamis dan jumat) dan masyarakat kelas ekonomi menengah ke atas. Sedangkan peluang pasar lainnya adalah para generasi milenial dan anak muda dikarenakan karakteristik sasirangan pewarna alam memiliki atribut warna yang soft, sesuai dengan selera anak muda. Akan tetapi pasar ini masih sulit untuk diberikan perhatian khusus, dikarenakan secara umum anak muda pada rentang usia 16-24 tahun (berpendidikan SMA/SMK sampai kuliah), belum banyak menghadiri acara-acara formal yang mengharuskan mereka menggunakan pakaian sasirangan. Selain itu, harga kain sasirangan pewarna alam yang relatif lebih mahal dibandingkan sasirangan dengan pewarna sintetis pada umumnya, juga menjadikan target konsumen anak muda menjadi kurang realistis.

\section{Target Produk Sasirangan Pewarna Alam}

Berdasarkan segmentasi di atas, ada 2 (dua) potensi pasar yang dapat dijadikan target pasar, yaitu (a) wisatawan dalam dan luar negeri; dan (b) Pejabat, ASN, dan karyawan swasta. Peluang pasar wisatawan baik dalam dan luar negeri relatif kecil, karena tidak banyak wisatawan yang datang ke Kalimantan Selatan. Para wisatawan pun secara umum belum banyak tertarik membeli kain khas dari Kalimantan Selatan ini, dikarenakan minimnya promosi produk Sasirangan. Sasirangan pewarna alam sebenarnya memiliki potensi yang sangat besar untuk pasar wisatawan, karena memiliki nilai kearifan lokal, merupakan warisan budaya, serta tone warna yang lembut, yang mana karakteristik warna seperti ini cenderung lebih disukai oleh wisatawan domestik dan mancanegara. Akan tetapi sangat disayangkan minimnya pemasaran dan promosi produk Sasirangan secara umum, menjadikan pengetahuan konsumen di luar daerah Kalimantan Selatan masih sangat minim. Bahkan, banyak wisatawan tidak mengetahui jika Kalimantan Selatan memiliki kain khas tradisional yang unik.

Peluang pasar ASN, pejabat pemerintah, dan karyawan swasta sangat besar. Kebijakan pemerintah provinsi, kabupaten dan kota di Kalimantan Selatan yang mewajibkan para ASN menggunakan kain sasirangan sebagai pakaian kerja di hari kamis dan jumat menjadikan mereka sebagai konsumen tetap yang sangat potensial untuk disasar. Para ASN pada umumnya memiliki pakaian sasirangan dengan berbagai warna, motif dan jenis, sehingga peluang untuk memasarkan produk sasirangan pewarana alam menjadi sangat potensial dengan keunggulan di tone warna yang lebih lembut, eksklusifitas produk, dan harga premium nya.

\section{Positioning Produk Sasirangan Pewarna Alam}

Produk sasirangan memang sangat mudah ditemui di Kalimantan Selatan, namun produk sasirangan yang menggunakan bahan-bahan alami masih sangat minim jumlahnya. Padahal ditingkat nasional dan mancanegara, produk fashion dari bahan alami ini sangat diminati, meskipun dari segi harga, produk-produk yang menggunakan pewarna alam harganya relatif lebih mahal dibandingkan sasirangan biasa. Positioning produk sasirangan pewarna alam berada pada satu kelas dengan produk tenun dan batik tulis, sebagai produk premium karena proses produksi yang lama, harga relatif mahal dan memiliki keunikan atau kekhasan tersendiri. Proses pembuatan sasirangan warna alam lebih lama jika dibanding dengan proses pembuatan sasirangan dengan warna sintetis, karena untuk menghasilkan warna yang diinginkan harus melalui ekstraksi bahan baku terlebih dahulu 
yang memerlukan waktu cukup lama dibanding dengan menggunakan pewarna sintetis yang sudah siap pakai. Begitu juga begitu juga dengan proses pewarnaannya yang lebih rumit, yakni proses pencelupan warna harus dilakukan berulang-ulang untuk mendapatkan intensitas warna yang diinginkan sehingga sasirangan yang menggunakan zat pewarna alam dengan bahan dan motif yang sama, harganya lebih mahal dibanding dengan sasirangan yang menggunakan pewarna sintetis.

Keunikan warna-warna kain sasirangan yang menggunakan pewarna alami adalah memiliki warna yang lebih lembut seperti warna pastel dan tidak mencolok seperti kain sasirangan pada umumnya (Ganie 2014). Selain itu, produk sasirangan pewarna alam juga tidak mengeluarkan warna yang persis satu sama lain, dan bahkan warnanya jika dicampur sesuai dengan teori warna yang ada maka bisa menjadi warna baru yang unik. Sasirangan dengan pewarna alam memberikan nuansa warna yang lebih natural sehingga berkesan unik dan eksklusif karena abstraksi zat pewarna alami mempunyai warna yang indah dan khas yang sulit ditiru dengan zat pewarna sintetik.

\section{Kebijakan Pengembangan Produk Sasirangan di Kota Banjarmasin}

Secara umum, untuk meningkatkan dan mempercepat pekembangan ekonomi kreatif di Kota Banjarmasin, khususnya pada subsektor kriya dalam hal ini adalah sasirangan pewarna alam, perlu dilakukan pendampingan dan pelatihan bagi perajin baik dalam pengembangan motif dan desain sasirangan dan pengolahan bahan baku pewarna alam secara lebih efisien, efektif dan berkesinambungan. Selain itu, perlu juga upaya terus menerus dalam hal memopulerkan produksi sasirangan dengan pewarna alam, sehingga akan lebih berpotensi dalam meningkatkan daya saing sasirangan pada pasar lokal di pasar domestik maupun mancanegara. Kebutuhan melakukan diversifikasi pewarna alam untuk beberapa kain yang digunakan untuk mendapatkan bahan alternatif yang mudah didapatkan dan lebih murah. Hal ini dirasa perlu sebagai langkah antisispasi dan subtitusi bahan kain dan pewarna yang ada, agar tidak terlalu tergantung bahan baku yang harus didatangkan dari pulau Jawa, serta mendorong pemanfaatan bahan lokal dan alami yang ramah lingkungan. Pemanfaatan bahan lokal dengan mengembangkan penggunaan serat dan pewarnaan alami dari tumbuh-tumbuhan alam sekitar untuk memajukan industri sasirangan pada subsektor kriya dan fashion.

Pemerintah perlu memberikan perhatian lebih terhadap bahan baku pewarna alam yang masih cukup sulit ditemui dipasar. Bahan baku pewarna harus diekstraksi terlebih dulu, sehingga pada prosesnya terdapat kerumitan tersendiri. Jika sudah banyak ditemui bahan baku pewarna alam yang sudah siap pakai di pasaran, tentunya akan memudahkan bagi para pengrajin untuk memproduksi sasirangan pewarna alam. Selain ketersediaan bahan baku, faktor standar kualitas dan keamanan produk dari bahan alami juga memerlukan perhatian yang tidak kalah penting. Hal ini dikarenakan produk fashion akan menempel langsung pada kulit kita, sehingga diperlukan standarisasi bahan baku dan proses pengolahannya, agar dapat dipertanggungjwabkan kualitas dan keamanan produknya.

Pada level pemasaran, Pemerintah Kota Banjarmasin dapat mengembangkan stategi pemasaran niche market/cerug pasar dan menempatkan produk sasirangan pewarna alam sebagai produk premium. Syarat yang harus dipenuhi adalah bahwa para pengrajin atau pelaku usaha dapat mempertahankan kualitas dan konsistensi pewarnaan, desain yang menarik, serta kombinasi warna yang mengikuti tren pasar. Hal ini akan sangat membantu mengangkat citra sasirangan di pasar lokal dan domestik, sehingga berpeluang untuk diangkat lagi di pasar internasional. Dalam hal ini, pelaku usaha dituntut untuk melakukan perencanaan operasinya dalam pasar yang ditinjau secara optimal, yaitu dengan jalan mencapai skala ekonomi dalam promosi, distribusi, pemanufakturan, dan sebagainya (Rosyadi 2020).

Pendampingan pelaku usaha mutlak diperlukan, khususnya pada pengrajin sasirangan pewarna alam. Pendampingan dalam hal pelatihan untuk teknik pewarnaan, 
ekstraksi, manajemen limbah, hingga pelatihan desain dan pemasaran digital sangat diperlukan agar pelaku usaha dapat konsisten dan kompetitif dalam operasional usahanya. Pelaku usaha membutuhkan penyuluhan dan pendampingan agar dapat melakukan transformasi model bisnis agar kompetitif dan dapat naik kelas. Transformasi dapat berupa modifikasi produk (dalam hal ini berubah dari penggunaan pewarna sintetis menjadi pewarna alami), digitalisasi usaha (baik dalam hal pemasaran maupun operasional usaha) hingga perubahan target pasar. Program yang telah dijalankan oleh pemerintah masih dirasakan belum dapat memberikan manfaat optimal bagi pelaku usaha, dikarenakan program pengembangan pendampingan masih bersifat project-based yang tidak memiliki suatu model pengembangan pendampingan yang sesuai dengan kondisi pelaku usaha dan sektor usaha yang didampingi.

\section{SIMPULAN DAN REKOMENDASI}

\section{Simpulan}

Kondisi pasar kerajinan kain tradisional sebenarnya memiliki potensi yang sangat besar, namun secara umum masih dikuasai oleh beberapa produk yang sudah terlebih dahulu melakukan pemasaran dan perencanaan pengembangan yang strategis seperti batik, tenun, dan songket. Di Provinsi Kalimantan Selatan, posisi kain sasirangan juga sudah sangat kuat, khususnya sasirangan pewarna sintetis, sasirangan bordir, dan sasirangan printing. Sedangkan sasirangan pewarna alam masih mencari posisinya di antara segmensegmen pasar yang telah ada. Meski demikian, hal ini juga memberikan ruang bagi produk sasirangan pewarna alam untuk dapat berkembang dengan mengambil pasar produk premium, seperti halnya batik tulis, songket dan tenun yang sudah merajai pasar kain tradisional premium di Indonesia. Preferensi konsumen dalam membeli produk sasirangan secara umum terdiri dari kombinasi warna, motif, kenyamanan, harga, pewarna alam, tren dan merek. Konsumen secara umum sangat sangat memperhatikan warna dan motif sebagai pertimbangan utama dalam memilih sasirangan. Di sisi lain, merek tidak menjadi prioritas utama, bahkan cenderung tidak diperhatikan dalam keputusan membeli, hal ini dikarenakan hampir tidak ada sasirangan bermerek yang dominan di Kalimantan Selatan.

Secara umum, hasil penelitian ini menegaskan bahwa pasar yang pas untuk produk Sasirangan pewarna alam adalah menempatkan produk sasirangan pewarna alam sebagai produk premium dan mengidentifikasi hal tersebut sebagai niche market atau segmen pasar dengan spesialisasi pada pewarna alam sebagai kunci utama. Faktor yang paling berpengaruh untuk kesuksesan niche market bagi industri pengrajin sasirangan pewarna alam di Kota Banjarmasin adalah pemasaran yang intensif melalui channel-channel yang tersedia. Namun, di sisi lain konsumen masih memiliki preferensi yang tinggi untuk langsung mendatangi gerai ataupun toko yang menjual produk sasirangan pewaran alam tersebut, hal ini dikarenakan konsumen merasa lebih nyaman membeli produk dengan menyentuh dan melihat langsung produk yang ingin dibeli.

\section{Rekomendasi}

Perlu adanya promosi produk yang berkesinambungan baik oleh pelaku usaha dan juga pemerintah daerah agar produk sasirangan dapat berada disatu level dengan kain khas daerah lainnya. Pola pendampingan juga harus dievaluasi, hal ini dikarenakan masih minimnya pendampingan yang ada bagi pelaku usaha sasirangan. Pendampingan tidak dapat disamakan dengan model pelatihan biasa yang project-based, namun harus dapat menjadi media konsultasi, pelatihan, penyuluan serta networking bagi pelaku usaha dalam mengembangkan usahanya. 


\section{DAFTAR PUSTAKA}

Howkins, John. 2001. Creative Economy: How People Make Money From Ideas. London: Pinguin Global.

Higgs, P, and S Cunningham. 2008. "Creative Industries Mapping: Where have we come from and where are we going?" Creative Industry Journal 7-30.

Ganie, Tajanudin B. 2014. Sasirangan Kain Khas Tanah Banjar. Kalimantan Selatan: Tuas Media.

Kotler, Philip, and Keller Lane. 2013. Marketing management 14th edition. New Jersey: Pearson.

Żelazny, R., \& Pietrucha, J. 2017. "Measuring innovation and institution: the creative economy index Equilibrium ." Quarterly Journal of Economics and Economic Policy 12(1), 43-62.

Hidayat, A. R., \& Asmara, A. Y. 2017. "Creative industry in supporting economy growth in Indonesia: Perspective of regional innovation system." In IOP Conference Series: Earth and Environmental Science. IOP Publishing. Vol. 70, No. 1, p. 012031 .

Darwanto. 2013. "Peningkatan Daya Saing Umkm Berbasis Inovasi dan Kreativitas (Strategi Penguatan Property Right terhadap Inovasi dan Kreativitas). ." Jurnal Bisnis dan Ekonomi (JBE) Hal. 142 - 149 Vol. 20, No. 2 ISSN: 1412-3126.

Newbigin, J. 2019. The creative economy-where did it come from and where is it going? In A Research Agenda for Creative Industries. . Edward Elgar Publishing.

Hussein, A. S., Rosita, N. H., \& Ayuni, R. F. 2019. "Knowledge management orientation behaviour and innovation: A lesson from Indonesia creative economy sector." International Journal of Sociotechnology and Knowledge Development (IJSKD) 11(1), 17-28.

Rosyadi, S., Haryanto, A., Kusuma, A. S., \& Fitrah, E. 2020. "The Role of Creative Economy in Promoting Sustainable Rural Development." International Conference on Social Transformation, Community and Sustainable Development.

Hoxha, J., \& Haska, E. 2019. Enterpreneurship Models Building Relations and Creative Economy".

Nurcahyo, R., Akbar, M. I., \& Gabriel, D. S. 2018. "Characteristics of startup company and its strategy: Analysis of Indonesia fashion startup companies. ." International Journal of Engineering \& Technology 7(2.34), 44-47.

Putra, A. D., \& Nasution, R. A. 2017. "Young-Adult Fashion Customer Psycographics Segmentation; Bandung Case Study." Journal of Business and Management 6(1), $1-20$.

Barnes, L. \& Lea-Greenwood, G. 2006. "Fast fashioning the supply chain: Shaping the research agenda." Journal of Fashion Marketing and Management 10(3), 259-2. doi. org/10.1108/13612020610679259.

Doyle, S., Moore, C. \& Morgan, L. 2006. "Supplier management in fast moving fashion retailing." Journal of Fashion Marketing and Management 10(3), 272-281.

Smith, K.T. 2017. "Mobile advertising to Digital Natives: preferences on content, style, personalization, and functionality",." Journal of Strategic Marketing. 
Stelzner, M. 2017. "Social Media Marketing Industry Report: Social media examiner, pp. 1-49."

Iosub, I., Ivanov, A. and Smedescu, D. 2016. "Characteristics and Development of Social Media as a Marketing Communications Tool." Journal of Emerging Trends in Marketing and Management Vol. 1, No. 1, pp. 339-345.

Powers, T. et al. 2012. "Digital and social media in the purchase decision process: A special report from the Advertising Research Foundation." Journal of advertising research, Vol. 52 No. 4, pp. 479-489, doi:10.2501/ JAR-52-4-479-489.

Shanthi, R., and Desti, Kannaiah. 2015. "Consumers' perception on online shopping." Journal of Marketing and Consumer Research, Vol 13 pp. 14-21.

Gulera, D. \& Parmar, Y.S. 2015. "A study of consumer preference for smartphone: A case of Solan town of Himachal Pradesh." International Journal of Management Research \& Review, 5(3) 1-20.

Katawetawaraks, C. \& Wang, C.L. 2013. "Online shopper behaviour: Influences of online shopping decision." Asian Journal of Business Research, 1(2) 66-74.

Lubis, A.N. \& Lumbanraja, P. 2016. "Service quality as key factor in revitalizing traditional markets through loyalty." International Journal of Applied Business and Economic Research, 14(11) 7881-7892.

Pradana, Herry A. 2020. "Peranan Sektor Ekonomi Kreatif Pada Pertumbuhan Ekonomi dan Ketenagakerjaan di Kalimantan Selatan." Jurnal Kebijakan Pembangunan, 13(1) 9-17. .

Pradana, Herry Azhar, and Siska Fitriyanti. 2019. "Pemberdayaan Dan Percepatan Perkembangan Badan Usaha Milik Desa (BUMDes) Dalam Peningkatan Ekonomi Masyarakat Dan Peningkatan Pendapatan Asli Desa." Jurnal Kebijakan Pembangunan, 14(2) 133 - 146. 
JURNAL Kebijakan Pembangunan Volume 16 Nomor 1 Juni 2021: 51 - 65 